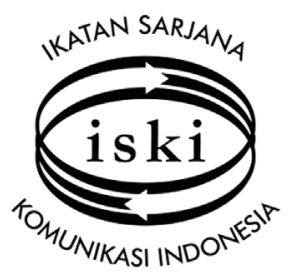

\title{
Intensity of Korean Drama Program in Television - Interactions of Peer Group, and its Influence Toward K-Style Imitation Behaviour Among Teenagers
}

\author{
Dita Kusumasari \\ Ministry of Communication and Information Technology \\ Jl. Merdeka Barat No. 9, Jakarta Pusat - Indonesia \\ dita001@kominfo.go.id
}

\begin{abstract}
Fashion has become a part of people's lifestyle, especially teenagers. The needs for identity-seeking and being recognized lead them to pay more attentions about certain things that are booming in their circles. Local trend can be spread quickly to entire world because of the improvement of mass media effect. Through Korean drama, Indonesian society has gained plenty information and details related Korean fashion, called K-Style. K-Style surprisingly attracted teens audience and motivated them to imitate this style. Peer Group Interactions also take an important role in K-Style imitation behavior. Necessities for being praised and accepted made their personality became capricious and emotionally unstable. For that reason, this study aims to analyze the influence of intensity of Korean drama program in television and Peer Group Interactions to K-Style imitation behavior among teenagers.
\end{abstract}

Keywords : Intensity, Media, Peer Group, K-Style, Imitation Behavior

\begin{abstract}
Abstrak
Mode merupakan bagian dari gaya hidup masyarakat, khususnya remaja. Pencarian identitas diri dan kebutuhan untuk diakui eksistensinya mendorong mereka untuk peka terhadap hal-hal yang sedang booming dalam lingkungan mereka. Perkembangan media massa menjadikan trend dan mode suatu negara dengan cepat menyebar secara global. Mode K-Style masuk dan berkembang di Indonesia melalui tayangan drama Korea, hingga menarik minat audiens untuk menerapkannya dalam penampilan mereka. Tindakan meniru tersebut dapat dikategorikan sebagai perilaku imitasi. Selain informasi media, interaksi dengan peer group juga dapat menjadi faktor pendorong dalam imitasi mode K-Style. Kebutuhan untuk diterima dan diakui oleh peer group nya membentuk kondisi saling menular dan mempengaruhi diantara mereka. Penelitian ini bertujuan untuk mengetahui pengaruh intensitas tayangan drama Korea di televisi dan Interaksi Peer Group terhadap Perilaku Imitasi K-Style di kalangan remaja.
\end{abstract}

Kata Kunci : Media, Peer Group, Remaja, Perilaku Imitasi 


\section{Introduction}

Technological developments in various aspects of life, especially in the field of communication led both distance and space getting smaller. Any information can be accessed easily and quickly, which is inseparable from the role of the media as a source of information for audience. This condition has impact on rapid flow of information, and encourages globalization. One of globalization forms which is quickly and easily accepted by the audience is the cultural globalization. Cultural globalization is characterized by the spread of values and particular culture to various places outside the area, so that the culture in certain country becomes a world culture.

Beside Western culture, the cultures of Japan and China have strong influences in various countries. These countries were known through their popular culture. The emergence of Korean popular culture became a strong competitor that shifted the position of those countries (Samudra, 2010: 8). Various products of Korean pop culture has entered the international market, including KDrama (Korean drama series), K-Pop (Korean pop music), KShow (Korean variety shows), and KStyle (Korean style and fashion). The global spread of Korean pop culture to various countries around the world has called as "Korean Wave".

The influx of Korean products in Indonesia began in 2002 through the melodrama "Endless Love" that was aired by private TV station--RCTI. Since then, plenty of melodrama and romantic comedy series such as Winter Sonata, Full House, Boys before Flower, and Descendants of the Sun started to emerge till recent time. Started in 2009, another private TV station-Indosiar even decided to air three title of Korean drama program each day. This composition indeed is a bold step, and has been maintained for almost 7 years, due to interests of the audience and their characteristics that could be interpreted by high share and rating of related program.

Furthermore, any issues regarding Korean became an interesting and trending topic for the audience, particularly Korean style and fashion (KStyle) that indirectly exposed through Korean drama. In consequence, KStyle is also being loved by Indonesian audience, especially teenagers. This can be seen through the emergence of teen groups that promoted as boy and girl band whose adapt the style and fashion of Korean. Following this trend, a lot of local boutique and make-up brand then produce and provide any clothes, cosmetics, accessories, and merchandise related to Korea.

The act of impersonating others can be categorized as behavioral imitation. This behavior mostly happened among teenagers. Teen years are a period of intense growth, not only physically but emotionally through some confusion and identity crisis. The nature and tendency to imitate their admired figures were process of discovering an identity (Gunarsa, 1991: 125). Teenagers tend to interact and mingle with people whose they considered to have certain similarities, such as a hobby, idol, favorite things and so forth. They need their existence being recognized by an environment through become a part of the environment itself. The needs to be "equal" and accepted by their peer group encouraged them to be aware and apply any trends that are booming in their circle, especially fashion. Certain factors such as seeking for identity, desire for being recognized, also similarity of the condition or hobby will form a mutual influence between them (Gerungan, 1988: 57).

Imitation of Korean culture began with KStyle, encouraged people to explore and find out more information about the culture. Korean pop music (K-Pop), lifestyles, food, also language, are series of imitation that happened next, which is a concrete symptoms of the fading of cultural values. Nowadays, teenagers tend to have more interest in studying and applying Korean culture than the culture of Indonesia itself. Without appropriate actions, this phenomenon could threaten the national identity.

Revolutions of technology, especially in communications have led people to the era of mass communication. Mass communication itself is a type of communication that uses the mass media to delivering message. It covers all channels (print and electronic), and happens when the communicator (source) is able to reach wide number of audience simultaneously, with relatively high speed (Wiryanto, 2000: 2).

Each person has their own motive and needs that defined preferences in using certain media. Uses and gratifications model is the approach of individual needs to media messages based on the principle of benefit and satisfaction. According to this model, there are various necessities that can be satisfied by mass media. At the same time, this necessity can be satisfied by other sources apart from mass media (Rachmat, 2003: 207). Different motives and reasons in consuming mass media cause audiences to react differently to mass media. Thus, different person may use similar media messages for different purposes, so 
that the effect of the mass media is also different in each individual.

Compared to other mass media (such as radio, movies, newspapers, magazines), television has special character. TV programs can be political, informative, entertaining, educative, or even combined with all of these elements. The information conveyed which is easy to be understood by audience because features are audible and clearly visible. Television creates certain atmosphere, which viewers can enjoy the program aired without particular preparation or intention. Further, the message delivery process is also as if done directly between the sender and receiver.

According to George Gerbner, TV has become second parents to children, teachers for the audience, and spiritual leaders who subtly convey the myth and values. Television serves to instill ideology, and the attempt to analyze it is known as cultivation analysis (Rachmat, 2003: 250). Cultivation analysis emphasis on the long-term exposure effects of television, which is an accumulation of all exposure received by audiences, and is designed to assess the contribution of the view of television on society concept related to social realities.

Cultivation theory analyzes the effects of television in the aspect of views, attitudes, and behavior of the audience. It also considers clear distinctions between the two groups, i.e. heavy viewers and light viewers, so that the intensity of watching television will affect the views, attitudes, and behavior of the audience. The difference between these groups is included mainstreaming concept (following the trend) in heavy viewers. This concept states that the higher the intensity of a person in watching television, the more resembles his/her perception of social reality with what was presented by television.

\section{Theoretical Framework}

In connection with Korean drama, they are often presents references of KStyle fashion in their programs. It influences the heavy viewers to take those concepts as a reality, so they will behave as what is presented in the show and applied in KStyle trend. Meanwhile, light viewers only assume Korean drama as an object, without seeing it as reality, so that the effect and influence toward this group is not as strong as heavy viewers.

The presence of television has various effects on the audience, include: (1). Cognitive effects, indicates by the change in terms of what is known, understood, or interpreted by audience. This effect is related to the transmission of knowledge, skills, trust, or information; (2) Affective effects, arises when there is a change in what is perceived, liked or hated by the audience. This effect is associated with emotions, attitudes, or values; (3) Behavioral effects, refers to the actual behavior that can be observed, which include patterns of action, activity, or habits.

Social interaction can be defined as a relationship between two or more individuals, where the behavior of one individual affect, change, or improve the behavior of others, or vice versa (Gerungan, 1988: 57). While peers or peer groups is a form of social groups where its member feel certain similarity to others, such as age, needs, or goals that strengthen the group (Santrock, 2003: 219). The formation of peer groups driven by conditions as follows: (1) the development of social process. Adolescents encounter a process of socialization in preparing to become an adult. This causes teens tend to seeking groups that suitable with their preferences so they can interact comfortably; (2) the needs to be appreciated. Psychologically, people need recognition from others in order to be satisfied by what has been achieved. Therefore individuals join their peers, which have the same psychological needs; (3) require the attention of others. Individuals need attention from others, especially from those who share the same fate. It can be found in the peer groups, where people feel equal one to another; (4) desire to find their world. Each member of peer groups has a common hobby, interest, or other things (Santrock, 2003: 221).

Combination of entertainment and information elements in the Korean drama aired on national television has delivering knowledge about the trend and fashion of KStyle. KStyle that displayed in Korean drama affects views, mindset and attitude of the audience. Attitude, which consists of knowledge coupled with judgement of an object, is determinant factor of a behavior.

Schramm (in Effendy, 1993: 76) argues that the presence of stimuli that stimulate individual attention of something, may underlie the emergence of interest. We might take the program and information about KStyle trend as an example of stimuli. A stimuli would get special attention if it meets the desires or needs of certain people, creating an interest in the individual. After going through decision-making process, this interest will be actualized in an action (the concept of attention, interest, desire, decission, 
action).

In modeling theories, William J. McGuire stated that the individual is deemed automatically tend to empathize with the feelings of people whose them observed, and imitate their behavior. We compare our behavior with people that we observe, that serves as a model. Mass communication displays variety models which will be imitated by the audience. Pictorial media such as television, movies, and comic dramatically demonstrate physical behavior that is easily emulated. Through television, people imitate the behavior of their idol. Impersonation theory was to explain why the media has an important role in spreading trends--speak, dressed, or other behavior (Rachmat, 2003: 216).

Adolescent is a stage to maturity. The period that occurs at the age of 12-22 is the transition from children to adulthood (Gunarsa, 1991: 125). Characteristics that appear among others: (1) identity search through the use of objects which is able to show the status symbols such as cars, clothing, and possession of physical things that are easily seen; (2) being ambivalent and unstable against any changes around them; (3) increased emotions due to physical and psychological changes so they become easily influenced; (4) fear of being rejected by peers if they do not act and dressed the similar way with their environment; (5) have an inquisitive nature of the information lead them tend to try something new; (6) identity confirmation is shown in the way they dressed, speak, and choosing idol; (7) begin to beautify themselves and utilize variety accessories to rise their confidence.

Korean dramas have indirectly spreading information of KStyle fashion so it provide reference then inspiring young generation to emulate or imitate the appearance of KStyle. Imitation is an encouragement to duplicating others behavior. In any imitation there are three steps that must be passed, namely: (1) Projection phase: Individuals gain an impression of something that would be imitated: (2) Subjective phase: Individuals tend to accept things that will be imitated, such as observing the attitudes and behavior of other individuals; (3) Objective phase: Individual has mastered their objects of imitation so they are eventually able to act like individuals who serve as a model (Santrock, 2003: 84).

KStyle imitation by teenagers is not only driven by Korean drama, but also interaction with group of peers. Peer group influence on teens often much greater than their parents or school. It even occurs in teenagers who had a good relationship with their parents and family. They identify the needs for being recognized and appreciated so that fear of being not accepted by peers if they do not look "similar" to the environment appears (Gunarsa, 1991: 125).

Theodore Newcomb proposes a model regarding influence process of group interactions, called "A-B-X System" (Goldberg, 1985: 51). This system involves three elements, namely $A$ and $B$ representing members of the group, and $\mathrm{X}$ as an issue or object of conversation. A and B need to achieve a state of balance between each other, also toward X. They need to agree on opinion about $\mathrm{X}$ to reach a balance condition. In this case, $\mathrm{X}$ reflects to KStyle. If A tends to admires and imitates KStyle trend, he/she will drive to influence or fix the orientation of other party (B) in order to have similar perception. On the other hand, $B$ naturally also has an initiative to change or match his/her orientation with A. This indicates that peer group interactions might create a condition of mutual contagious and influence among them, including imitation behavior of a trend.

Based on the explanation above, the intensity of watching Korean dramas on television, peer group interactions, and KStyle imitation behavior among teenagers can be described in geometrical as follows:

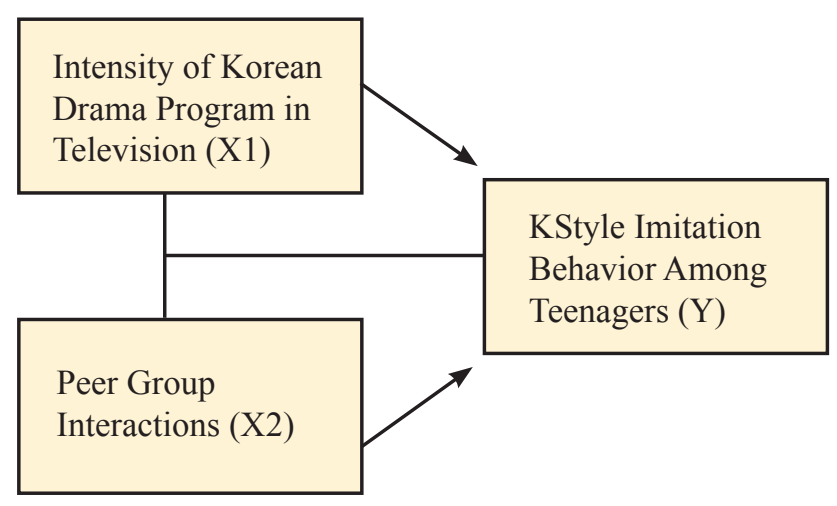

The influence of intensity of Korean drama program in television (X1) and Peer Group Interactions (X2) toward K-Style imitation behavior among teenagers (Y)

\section{Material and Methodology}

The type of this study is explanatory that explains the causal relationships between variables by hypothesis testing (Singarimbun, 1995: 5). Causal Relationships can be examined through observation of the consequences that have occurred. Survey methods with quota sampling have been used in this study. Selection of the sample based on certain consideration and criteria up to the desired quota is being reached. This technique applied is due to large and uncertain 
population (Somantri, 2006: 83).

Accordingly, sampling was divided into two representative groups the population, with total amount of 84 people. The first group was members of 'K-Elf' (Korean Everlasting Friends) community in Semarang aged 16-18 years, as many as 43 people. While the second groups amounted 41 people, which is total student of class XI IA-2 of State Senior High school 7 in Semarang (general). Both groups were decided based on the consideration that the age range of high school students are classified in the phase of intermediate teen. In this phase, transition process from kids towards adulthood has been revealed. Some characteristics that seem obvious including an effort of seeking for identity through the use of physical objects that is easily seen as a status symbol, also appearance that oriented to their idol (Gunarsa, 1991: 125).

\section{Result and Discussion}

Based on the research, the percentage of respondents identity based on gender is as follows.

Table 1

Percentage of Respondents By Gender

\begin{tabular}{|l|l|c|c|}
\hline No. & Gender & Quantity & $\%$ \\
\hline 1. & Male & 36 & 42,9 \\
\hline 2 & Female & 48 & 57,1 \\
\hline & Total & 84 & 100,0 \\
\hline
\end{tabular}

The table above shows almost equal numbers of male and female respondents, from a total of 84 respondents.

The increase of mass media existence help the audience to access any information easier. One of media that can reach broad audience at the same time is television. There are plenty messages and information conveyed by television, includes the trend of KStyle. This trend spread through various channels, mostly through Korean dramas that have been regularly aired by television. Response of audience to the show can be measured by the intensity of watching the show that includes aspects of quantity and quality.

Aspect of quantity measured by the frequency, duration, as well as whether there is particular time spent on watching Korean dramas. While the quality aspect includes tendency to watch the show as whole, the reason to watch (story, characters, fashion, filling time), attention (to the characters and storyline), understanding of K-Style trend which are presented in the show (origin and type), also knowledge of Indonesian figures who adapt Korean Style. Based on thirteen statements regarding the intensity of watching Korean drama in television submitted to the respondents, it can be categorized as follows:

$\mathrm{I}=\frac{\mathrm{R}+1}{\mathrm{~K}}$

Information:

I = interval

$\mathrm{R}=$ the difference between highest and lowest score

$\mathrm{K}$ = number of classes

Noted:

$\Sigma$ questions $=13$

Lowest score $=1 \times 13$ questions $=13$

Highest Score $=4 \times 13$ questions $=52$

$\mathrm{K}=4$ classes

Thus:

$$
\begin{aligned}
I & =\frac{(52-13)+1}{4} \\
& =10
\end{aligned}
$$

With intervals of 10 , it is obtained:

13-22: low category

23-32: medium category

33-42 : high category

43-52 : very high category

Of the four categories above, the intensity of watching Korean dramas on television between teenagers illustrated in the following diagram:

\section{Diagram 1}

Percentage of Respondents

Based on the Intensity of Korean Drama in Television

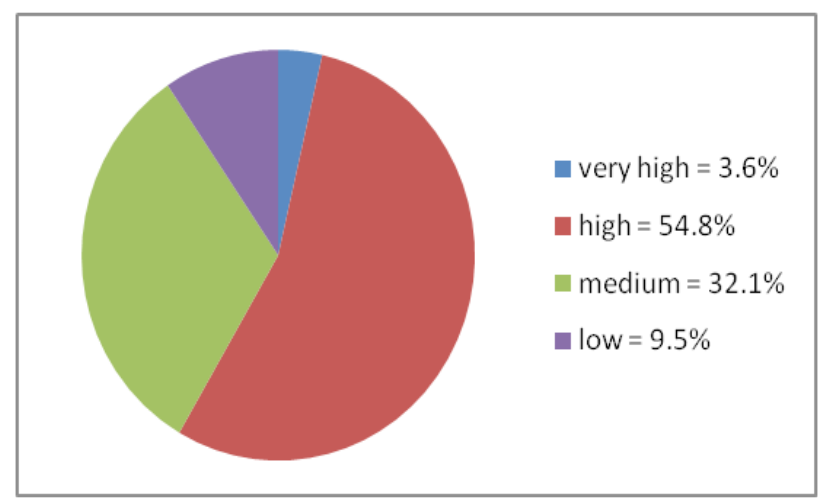


Diagram 1 show that the largest percentage is occupied by high categories, which is more than half of total respondents. This indicates the quantity and quality of respondents that quite high in watching Korean dramas on television daily. The high frequency and duration of watching a show, are accompanied by concern and well rounded understanding, make the audience being able to grasp the ideas and information presented properly.

Adolescence is a period of transition from children to adulthood. The needs to socialize and desire to be understood and develop themselves, has led them to form or join a peer group. In the peer group interactions, individual behaviors may influence, alter, or fix the behavior of others. This process occurs due to conformity or uniformity in the group. Passion and interest in K-Style might be formed through the peer group interactions. Here is a measure of peer group interactions, which includes frequency, duration, consistency, topics/issues (personal, trends, music and movies, assignment/exam), attention and understanding of the topic shared during interaction, also frequency and duration of any discussions regarding K-Style. Based on eleven points related to interaction with peer groups, it can be categorized as follows:

11 - 18.5 : low category

19.5 - 27 : medium category

28 - 35.5 : high category

36.5 - 44 : very high category

Of the four categories above, peer group interactions among teenagers can be seen in the following diagram:

\section{Diagram 2}

Percentage of Respondents by Peer Group Interactions

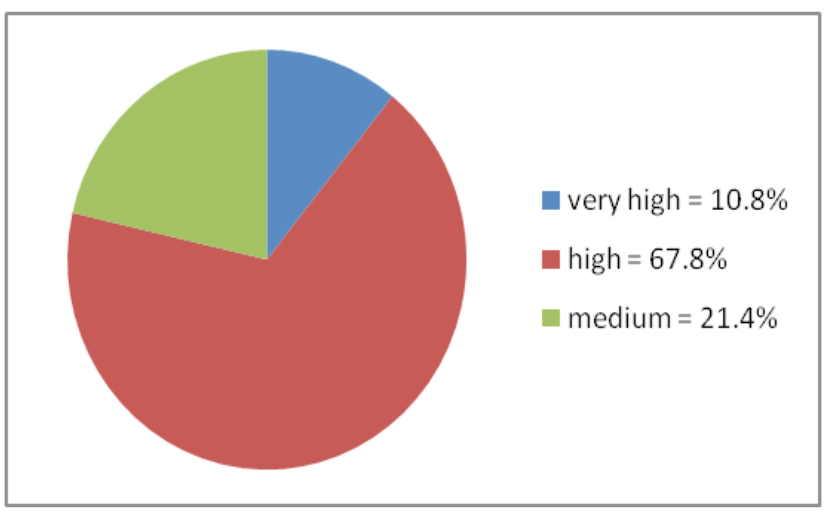

Diagram 2 above shows that there is no respondents were included in low category. This is because respondents are in the adolescent age range, which have the needs of self-actualization in the form of recognition and appreciation by people and their environment, especially peers. Respondents found them safety and comfort in their groups. These conditions encourage respondents to be enthusiastic and concerned with most topics or issues discussed during the peer group interactions.

Imitation behavior is the desire to imitate or reproduce certain actions of others. KStyle imitation is an example to this behavior. Here is a measure of behavioral imitation of KStyle that can be viewed through several items of questions including interest, information search of KStyle, as well as the identification of behavioral imitation of K-Style which is judged through application of hair style, fashion, and custom make-up. Based on six statements that have been submitted to the respondents, it can be categorized as follows:

\section{$6-9.75 \quad$ : low category \\ 10.75 - 14.5 : medium category \\ 15.5 - 19.25 : high category \\ $20.25-24$ : very high category}

Of the four categories, imitation behavior of KStyle among teenagers is illustrated in the following diagram:

\section{Diagram 3 \\ Percentage of Respondents Based on Imitation Behavior of Kstyle}

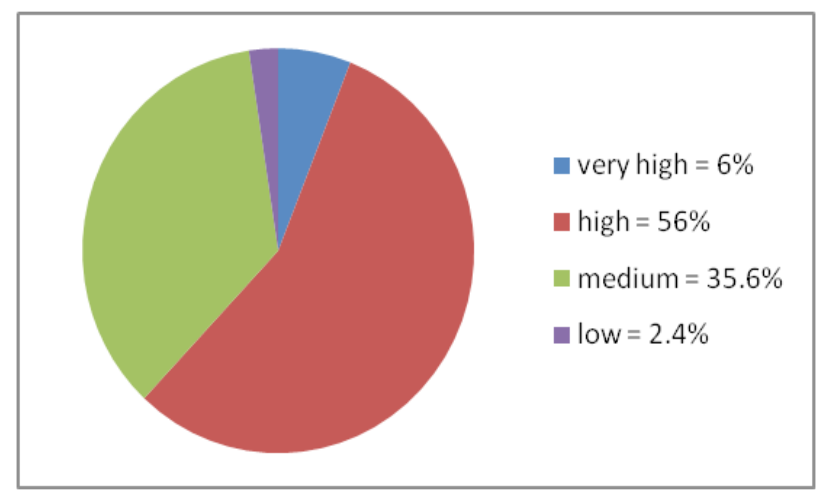

In accordance with Diagram 3, the high category had the highest number of respondents. These results indicate that majority of respondents are interested in applying diverse types of KStyle that has been enter- 
ing to Indonesia since 2009, either in hairstyles, fashion or make-up.

\section{Hypothesis testing}

In this research, hypothesis testing is done through regression analysis to measure the influence of independent variables on the dependent variable. The study involves two independent variables (intensity of watching Korean drama in television/X1, peer group interactions/X2) and one dependent variable (imitation behavior of KStyle) so that the analysis that needs to be applied is multiple regression (Sarjono, 2011: 91). The model used as follows:

$$
Y=\beta_{0}+\beta_{1} X_{1}+\beta_{2} X_{2}+\beta_{3} X_{3}+\ldots+e
$$

noted:

$\mathrm{Y}$ : dependent variable

$\beta$ : regression coefficients

$\mathrm{X}$ : variables

e: standard error

The accuracy of regression sample function can be measured by coefficient of determination and the statistical value F. Coefficient of determination (R2) measures the model ability of explaining variations in the dependent variable. Coefficient of determination values is between 0 and 1 . Smaller value of R2 means the limited ability of independent variables (X1 and X2) in explaining the variation of the dependent variable $(\mathrm{Y})$, while value that is close to 1 indicates the capability of independent variables in delivering nearly all informations needed to predict the variation of dependent variable.

Simultaneous significance test or F-test basically indicates whether all independent variables included in the model have a mutual influence to the dependent variable. The significant provisions among others: 1 . If the significance value $\leq 0.01$ : the influence of independent variables is highly significant at confidence level of $99 \%$ so that the null hypothesis (H0) is rejected and the alternative hypothesis (Ha) is accepted.

2. If the significance value $\leq 0.05$ : the influence of independent variables is significant at confidence level of $95 \%$ so that the null hypothesis ( $\mathrm{H0})$ is rejected and the alternative hypothesis $(\mathrm{Ha})$ is accepted.
If the significance value $\geq 0.05$ : the influence of independent variables is not significant at confidence level of $95 \%$ so that the null hypothesis (H0) is accepted and the alternative hypothesis ( $\mathrm{Ha}$ ) is rejected (Sarjono, 2011:112).

\section{Data Analysis}

Multiple regression analysis has been applied in order to measure the influence of intensity of Korean drama program in Television (X1) and Peer Group interaction (X2) towards K-Style Imitation Behavior among teenagers $(\mathrm{Y})$, which yields following equation models:

$$
Y=(1,139)+0,084 X_{1}+0,362 X_{2}
$$

\section{Table 2}

Coefficients

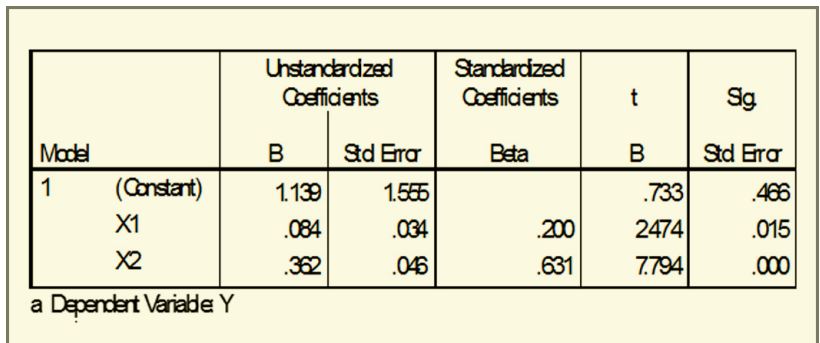

Table 2 shows the positive value of coefficient. It indicates that every additional value to variable $\mathrm{X} 1$ will give a rise score of $\mathbf{0 , 0 8 4}$; and each addition value of variable X2 would give a rise score of $\mathbf{0 . 3 6 2}$.

Individual parameter testing is done by comparing $t$ arithmetic with $t$ table. A total respondent of 84 people has obtained $d f$ (degree of freedom) value of 82. $t$ table value for $d f$ of 82 , at significance level of 0.05 is 1.66 .

Variable X1 obtain $t$ value of 2.474 with significance value 0,015 . Therefore $t$ arithmetic $>t$ table $(2.474>1.66)$ so that $\mathrm{HO}$ is refused and $\mathrm{Ha}$ is accepted. The significant value of 0.015 is below 0.05 for confidence level of $95 \%$. This results shows that the independent variable (X1) has a significant effect on the dependent variable $(\mathrm{Y})$.

While variable $\mathrm{X} 2$ has $t$ value of 7.794 with significance value of 0.000 . Thus the value of $t$ arithmetic $>t$ table $(7.794>1.66)$ so that $\mathrm{HO}$ is also refused and $\mathrm{Ha}$ is accepted. The significant value of 0.000 is below 0.01 for confidence level of $99 \%$. The result of this test shows that the independent variable (X2) has a highly significant influence on the dependent variable $(\mathrm{Y})$. 
Table 3 Analysis of Variance

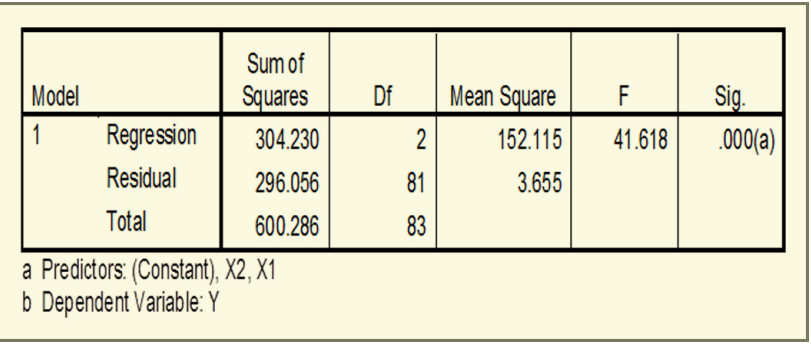

Based on $F$-test, $F$ value obtained equal to 41.618 with significance value of 0.000 for confidence level of 99\%. The result of the test shows that the independent variables (X1 and $\mathrm{X} 2$ ) simultaneously have a significant effect on the dependent variable $(\mathrm{Y})$.

Further, the calculation of multiple regression tests has obtained the coefficient of adjusted determination (Adjusted R2) of 0648 with Standard Error of Estimate (SEE) 1,912. It means that the influence of variables $\mathrm{X} 1$ and $\mathrm{X} 2$ towards $\mathrm{Y}$ is equal to $\mathbf{6 4 . 8 \%}$, and the value of other variables that affect variable $\mathrm{Y}$ is equal to $35.2 \%$.

Table 4

Model Summary

\begin{tabular}{|l|l|r|r|r|}
\hline Model & $\mathrm{R}$ & R Square & $\begin{array}{c}\text { Adjusted R } \\
\text { Square }\end{array}$ & $\begin{array}{c}\text { Std. Erro of } \\
\text { the Estimate }\end{array}$ \\
\hline 1 & $.812(\mathrm{a})$ & .660 & .648 & 1.912 \\
\hline
\end{tabular}

a Predictors: (Constant), X2, X1

Based on the test results, the research hypothesis which states that "there are linear influence between the intensity of Korean dramas on television and interaction with peer group towards KStyle imitation behavior among teenagers" is acceptable. This means that either stands alone or together, both of independent variables (X1 and $\mathrm{X} 2$ ) could affect the dependent variable $(\mathrm{Y})$.

\section{Conclusion}

Korean fashion style or often referred to KStyle, entering and progressing in Indonesia through Korean drama program. KStyle is being loved and applied by Indonesian teenagers to their daily appearance, either in clothes or make-up. The act of impersonat- ing itself can be categorized as imitation behavior. In majority, this behavior has struck the adolescents due to tendency to imitate their admired figure or idols as a form of identity-seeking. Imitation behavior of fashion was allegedly caused by several factors, including the intensity of watching television program and interaction with the peer group.

In accordance with the purpose of the study to analyze the influence of intensity of Korean drama program in television and peer group interactions toward KStyle imitation behavior among teenagers, the conclusions that can be drawn in this study are: (1) The high intensity of Korean dramas on television encourage the audience to view the ideas presented in the show as a reality and behave like what was shown in the program, providing a significant and linear effect of K-Style imitation behavior among teenagers; (2) Partially, peer group interaction may affect, change, or improve the behavior of other individuals in a group, so as to give linear and significant impact on the behavior of K-Style imitation among teenagers; (3) Together, the intensity of Korean dramas on television and peer group interaction were able to explain the occurrence of K-Style imitation behavior among adolescents by $64.8 \%$. While $35.2 \%$ is explained by other variables.

In conclusion, recommendations in this study are as follows: (1) audience should be selective and wise at filtering any content and information contained in the media, so they would be capable to distinguish between social reality and reality of media. At this rate, they would find that it is not necessary to mimic any behavior of the show; (2) Korean drama program have an important role on imitation behavior of KStyle, so that the media especially television as source of information and entertainment, is expected to provide enough educative and useful program for public. In addition, they should consider the frequency and duration of the program that contains foreign culture elements; and (3) the high influence of peer group on adolescents should receive more attention and supervision of the parents/teacher, for example by facilitating their hobby or community in order to be worthwhile and give a positive impact.

\section{References}

Azwar, Saifuddin. (1998). Metode Penelitian. Yogyakarta: Pustaka Pelajar.

Alatas, Alwi. (2004). Remaja Gaul Nggak Mesti Ngawur. Bandung: Mizan Pustaka. 
Effendy, Onong Uchjana. (1993). Ilmu, Teori, dan Filsafat Komunikasi. Jakarta: PT. Citra Aditya Bakti.

Garett, Henry E. (1961). General Pshycology. New York: American Book Company.

Gerungan, W. A. (1988). Psikologi Sosial. Bandung: PT. Eresco.

Ghozali, Imam. (2006). Aplikasi Analisis Multivariate dengan Program SPSS. Semarang: Badan Penerbit Undip.

Goldberg, Alvin A. (1985). Komunikasi Kelompok (Proses - proses Diskusi dan Penerapannya). Jakarta: UI-Press.

Gunarsa, Singgih D. (1991). Psikologi Perkembangan Anak dan Remaja. Jakarta: Gunung Mulia.

Hadi, Sutrisno. (1983). Analisis Regresi. Yogyakarta: Andi Offset.

Hurlock, Elizabeth B. (1993). Perkembangan Anak. Jakarta : Erlangga.

Liliweri, Alo. (1991). Memahami Peran Komunikasi dalam Masyarakat. Jakarta: PT. Citra Aditya Bakti.

Malcolm, Hardy. (1988). Pengantar Psikologi. Jakarta: Erlangga.

McQuail, Dennis. (1996). Teori Komunikasi Massa (Suatu Pengantar). Jakarta: Erlangga.
Monks, F.J dan Knoers. (2002). Psikologi Perkembangan: Pengantar dalam Berbagai Bagian. Yogyakarta: Gadjah Mada University Press.

Nurudin. (2004). Komunikasi Massa.Malang : Cespur.

Rahardjo, Turnomo. (2009). Cetak Biru Teori Komunikasi dan Studi Komunikasi di Indonesia. Jakarta.

Rakhmat, Jalaludin. (2003). Psikologi Komunikasi (edisi revisi). Bandung: PT. Remaja Rosdakarya.

Samudra, M. (2010).Kamus Hebat Bahasa Korea. Yogyakarta: Cemerlang Publishing.

Santoso, Singgih. (2000). Buku Latihan SPSS Statistik Parametrik. Jakarta: Elex Media Komputindo.

Santrock, John W. (2003). Adolescence: Perkembangan Remaja (edisi keenam). Jakarta: Erlangga.

Sarjono, Haryadi. (2011). SPSS vs LISREL Sebuah Pengantar, Aplikasi Untuk Riset.Jakarta: Salemba Empat.

Singarimbun, Masri. (1995). Metode Penelitian Survei. Jakarta: PT. Pustaka LP3ES Indonesia

Somantri, Ating. (2006). Aplikasi Statistika dalam Penelitian. Bandung: Pustaka Setia.

Wiryanto. (2000). Teori Komunikasi Massa. Jakarta: PT Grasindo 